\title{
Evaluation of Knowledge and Attitude of Parents of Asthmatic Children on the Seasonal Flu Vaccine
}

\author{
Astımlı Çocukların Ebeveynlerinin Mevsimsel Grip Aşısı ile Illgili Bilgi ve \\ Tutumlarının Değerlendirilmesi
}

\author{
Sanem Eren Akarcan'(iD), Eda Karadağ Öncel2(ID), Tuba Tuncel³(iD), Emine Ece Özdoğru'(iD), Dilek Yılmaz Çiftdoğan(iD) \\ ${ }^{1}$ Clinic of Pediatric Allergy and Immunology, SBU Izmir Tepecik Training and Research Hospital, Izmir, Turkey \\ ${ }^{2}$ Division of Pediatric Infectious Diseases, SBU Izmir Tepecik Training and Research Hospital, Izmir, Turkey \\ ${ }^{3}$ Division of Pediatric Allergy and Immunology, İzmir Katip Çelebi University Faculty of Medicine, İzmir, Turkey \\ ${ }^{4}$ Division of Pediatric Infectious Diseases, Izmir Katip Çelebi University Faculty of Medicine, İmir, Turkey
}

Cite this article as: Eren Akarcan S, Karadağ Öncel E, Tuncel T, Özdoğru EE, Yılmaz Çiftdoğan D. Evaluation of knowledge and attitude of parents of asthmatic children on the seasonal flu vaccine. J Pediatr Inf 2021;15(3):e127-e132.

\section{Abstract}

Objective: Flu is a respiratory illness caused by influenza viruses. Because of their high risk of serious flu complications, asthma patients are recommended to receive seasonal flu vaccine every year. However, it is observed that the vaccination rates in this group vary from society to society and are generally low. In this study, it was aimed to evaluate the knowledge and attitudes of parents of asthmatic children about seasonal flu vaccine.

Material and Methods: Parents of children with asthma between the ages of 3 and 18 who applied to our hospital's Pediatric Allergy Clinic between November 2019 and February 2020 and followed up for at least 6 months with a diagnosis of asthma were included in the study. Participants were asked to answer a questionnaire containing the demographic information about their families and their knowledge and attitudes about the seasonal flu vaccine.

Results: Parents of 128 children with asthma were included in the study, $81.3 \%$ of the questionnaires were answered by mothers and $59.4 \%$ of the patients were male. While $57.8 \%$ of the parents stated that they had any knowledge about the flu vaccine, $47.6 \%$ knew that patients with asthma were at high risk for flu and $23.4 \%$ knew that the vaccine was free for these patients. The most frequent sources of information were doctors (59.5\%), radio-TV programs $(24.3 \%)$ and the internet $(21.6 \%)$. At least once vaccination rate lifetime in asthmatic children and parents were $31 \%$ and $5 \%$, respectively. While the most common reasons for vaccination were doctor's recommendation (75\%) and being at high illness risk $(35 \%)$, the most common reasons for not being vaccinated were not
Öz

Giriş: Grip, influenza virüslerinin sebep olduğu bir solunum yolu hastalığıdır. Ciddi grip komplikasyonları açısından yüksek risk altında olmaları nedeniyle, astım hastalarına her yıl mevsimsel grip aşısı yapılması önerilmektedir. Bununla birlikte bu grupta aşılanma oranlarının toplumdan topluma değiştiği ve genelde düşük olduğu görülmektedir. Bu çalışmada, astımlı çocukların ebeveynlerinin mevsimsel grip aşısı hakkındaki bilgi ve tutumlarının değerlendirilmesi amaçlanmıştır.

Gereç ve Yöntemler: Çalışmaya hastanemiz Çocuk Alerji Kliniği'ne Kasım 2019-Şubat 2020 tarihleri arasında başvuran, astım tanısıyla en az 6 aydır izlenen 3-18 yaş arası astımlı çocukların ebeveynleri dahil edildi. Katılımcılara aileleriyle ilgili demografik bilgileri ve mevsimsel grip aşıડı hakkındaki bilgi ve tutumlarını içeren sorulardan oluşan bir anket uygulandı.

Bulgular: Çalışmaya 128 astımlı çocuğun ebeveyni alındı. Anketlerin \%81.3'ü anneler tarafından yanıtlanmıştı. Hastaların \%59.4'ü erkekti. Ebeveynlerin \%57.8'i grip aşısı hakkında bilgisi olduğunu belirtirken, \%47.6'sı astımlı hastaların grip komplikasyonları açısından yüksek risk grubunda olduğunu, \%23.4'ü astım hastalarına aşının ücretsiz olduğunu biliyordu. Bilgi kaynağı olarak en sık doktorlar (\%59.5), radyo-TV programları (\%24.3) ve internet (\%21.6) gösterilmişti. Astımlı çocuklarda yaşam boyu en az bir kez aşılanma oranı \%31 iken, bu oran ebeveynlerde \%15'ti. En sık aşı yaptırma nedenleri doktor önerisi (\%75) ve riskli grupta olma (\%35) iken, aşı olmama nedenleri aşı hakkında yeterli bilgi sahibi olmama (\%36.1) ve aşının yan etki yapmasından korkmaydı (\%32.1). Hastalar herhangi bir za-

Correspondence Address/Yazışma Adresi

Sanem Eren Akarcan

SBÜ İzmir Tepecik Eğitim ve Araştırma Hastanesi,

Çocuk Alerji ve İmmünoloji Kliniği,

İzmir-Türkiye

E-mail: saneren@yahoo.com 
having enough information about the vaccine (36.1\%) and being afraid of vaccine side effects (32.1\%). Patients were grouped as those who had the seasonal flu vaccine at any time and those who did not. It was observed that in the vaccinated group the follow-up period was longer, the rates of having any knowledge about the flu vaccine, knowing that flu has a high complication risk in asthmatics and the vaccine is free for asthmatics were higher compared to not vaccinated ( $p<0.001$ for all). While the majority of those who said that they received information from the doctor were among those vaccinated $(p<0.001)$, it was more common for those who were not vaccinated to obtain information from the internet $(p=0.004)$.

Conclusion: It has been observed that the rate of flu vaccination is low in children with asthma. It was noted that the vaccination rate was higher if the information was obtained from the doctors, and the follow-up period was longer in the vaccinated patients. For this reason, it is thought that physicians informing parents at every control and especially before the flu season will increase the rates of getting flu vaccines in children with asthma.

Keywords: Asthma, children, flu vaccine, parental knowledge

\section{Introduction}

Flu is a contagious respiratory tract disease caused by influenza viruses (Influenza A and B) and may lead to seasonal epidemics. In severe cases, hospitalization and death may occur. Children aged under 5 years, adults aged over 65 years, pregnant women, and individuals with asthma or other pulmonary diseases, cardiac diseases, neurologic, and metabolic diseases are risk groups in terms of serious influenza complications $(1,2)$. Thanks to seasonal vaccination, mortality risk may be lowered in half in these risk groups (3).

Asthma is a respiratory tract disease characterized with chronic inflammation of the airways. It is the most common chronic disease of the childhood and the most important reason of hospitalization in children aged under 15 years (4-6). Asthma attacks can be triggered by respiratory tract infections, allergens, chemical irritants, and air pollution $(5,7)$.

Patients with asthma are under high risk in terms of serious flu complications even though their asthma is mild or symptoms are under control with drugs. Flu infection may trigger an asthma attack by increasing inflammation in the airways and lungs and may worsen asthma symptoms. Asthma is the most common accompanying disease in children hospitalized due to flu (8).

Asthmatic patients are recommended to get the seasonal flu vaccine every year since they are in high risk group in terms of flu complications $(2,9,10)$. Nonetheless, it is observed that vaccination rates in this group vary from community to community and year to year and usually remain low. Vaccination rates, which were $10-20 \%$ in Europe and $30-40 \%$ in the Unites States of America reached $30 \%$ and $55 \%$ respectively following the effects of vaccination campaigns after the $2009 \mathrm{H} 1 \mathrm{~N} 1$ epidemic (11-14). In our country, seasonal vaccination rates in children with asthma have been reported as $15-52 \%$ in studies conducted in different centers and different flu seasons (15- manda mevsimsel grip aşısını olanlar ve olmayanlar olarak gruplandı. Aşılanan grupta aşılanmayan gruba göre takip süresinin daha uzun olduğu, grip aşısı hakkında bilgi sahibi olma, astımlılarda gribin yüksek komplikasyon riski olduğunu ve aşının astımlılara ücretsiz olduğunu bilme oranlarının daha yüksek olduğu görüldü (her biri için $p<0.001$ ). Aşılananlar arasında doktordan bilgi aldığını söyleyenler çoğunlukta iken ( $p<0.001)$, aşılanmayanlarda bilgiyi internetten alma daha sıktı $(p=0.004)$.

Sonuç: Astımlı çocuklarda grip aşısı yapılma oranlarının düşük olduğu görülmüştür. Bilgi doktorlardan alındığı takdirde aşılamanın daha yüksek olduğu ve aşılanan hastalarda takip süresinin daha uzun olduğu dikkat çekmiştir. Bu nedenle hekimlerin her kontrolde ve özellikle grip sezonu öncesinde ebeveynleri bilgilendirmelerinin astımlı çocuklarda grip aşıડı yaptırma sıklığını arttıracağı düşünülmüştür.

Anahtar Kelimeler: Astım, çocuk, grip aşısı, ebeveyn bilgi düzeyi

17). A study conducted in our city on this subject could not be found.

Understanding the vaccination rates of children followed for asthma and the factors affecting these rates will contribute to increase the vaccination rate at the desired level. In this study, it was planned to investigate the knowledge and attitude of the parents of asthmatic children on seasonal flu vaccine.

\section{Materials and Methods}

This cross-sectional study was conducted with patients aged 3-18 years followed for asthma for at least 6 months and their parents presenting to the Pediatric Allergy Clinic of our hospital between November 2019 and February 2020. Approval was received from the SBÜ İzmir Tepecik Training and Research Hospital Non-Interventional Clinical Research Ethics Board prior to our study (Date: 13/11/2019, Decision no: 2019/16-7).

Asthma diagnosis was made according to the criteria designated for patients aged under and over 5 years in the guideline of "Global Initiative for Asthma (GINA) (18). The parents were informed on the study. Parents that agreed to participate in the study, knew Turkish and in whose children no additional chronic disease other than allergic disease was present were included into the study. After obtaining written consent from the parents, they were asked to fill out a survey containing 22 questions oriented at demographic information of the patient and his/her family (the sex of the participating parent and the patient, education status of the participating parent, school or kindergarten status of the patient, the number of people living in the house, the presence of individuals at risk aged under 5 years and over 65 years, smoking status at home) and at their knowledge and attitude towards the seasonal flu vaccine (whether or not they had any information on the flu vaccine, what their sources of information are, whether or not they got the flu vaccine before, and if not, the reasons for not 
getting the vaccine, if yes, the reasons for getting the vaccine, whether or not they knew that asthmatic children were in the high risk group in terms of the flu disease, whether or not they knew that these patients could get the vaccine free of charge, and whether or not they would get the flu vaccine in this flu season). The questions were read aloud and the responses were marked for illiterate parents. Seven questions regarding the age at diagnosis, duration of follow, allergen susceptibility, additional allergic disease, the use of controlling drugs, and whether or not asthma was under control were responded by the physician following the patient. All parents were informed on the flu vaccine after the implementation of the survey.

\section{Statistical Analysis}

Statistical analyses of the data were performed using IB$M^{\circledR}{ }^{\circledR} P S S^{\circledR}$ V24 (IBM Corp, NY, USA) statistical package. Continuous variables were expressed as mean \pm standard deviation (SD) or median (min-max) as per distribution qualities. Chi square test or Fisher test was used for the comparison of categorical variables, and Student's t test or Mann Whitney $U$ test was used for the comparison of continuous variables. Statistical significance was set at $p<0.05$.

\section{Results}

Parents of 128 asthmatic children were included into the study. Of the surveys, $81.3 \%$ were responded by mothers. Of the patients, $59.4 \%$ were males and $40.6 \%$ were females. Mean age of the parents participating in the survey was $38.6 \pm 5.5$ years, and mean age of the patients was $9.7 \pm 3.4$ years. Of the patients, $88.3 \%$ were older than 5 years of age. Of the parents, $46.1 \%$ stated that they received high school and higher education, and $95.3 \%$ indicated that they were married. Median number of people living in the house was 4 (min-max: 2-8). Of the patients, $89.8 \%$ continued school or kindergarten. At least one individual at risk apart from the patient (aged $<5$ years or $>65$ years) was living with $32 \%$ of the families. Smoking was present in the homes of $62.5 \%$ of the patients, and the place of smoking was reported mostly as the balcony/outside the house (91\%).

When disease characteristics of asthmatic children were questioned, median age at diagnosis was 6.0 (min-max: 1-16) years, and median follow-up duration was 3.0 (min-max: 0.514) years. Of the patients, $69.8 \%$ was susceptible to at least one allergen, and $39.4 \%$ had additional diseases like allergic rhinitis (88.1\%) and skin allergies (7.1\%). Of the patients, $76.1 \%$ used at least one drug for asthma, and the disease was completely under control in $62.4 \%$. Table 1 shows the demographic data of the patients and the families and the clinical features of the asthmatic children.

When the knowledge and attitude of the parents regarding flu and flu vaccine were questioned, while $57.8 \%$ stated that they were informed on the flu vaccine, $47.6 \%$ knew that
Table 1. Demographic and clinical caharcteristics of the participants

\begin{tabular}{|c|c|}
\hline Characteristic & \\
\hline Age of the parent (year)* & $38.6 \pm 5.5$ \\
\hline Age of the patient (year)* & $9.7 \pm 3.4$ \\
\hline Sex of the patient $(\text { male) })^{* *}$ & $76(59)$ \\
\hline $\begin{array}{l}\text { Education status of the parent } \\
\text { Illiterate } \\
\text { Primary school } \\
\text { Secondary school } \\
\text { High school } \\
\text { University }\end{array}$ & $\begin{array}{c}3(2.3) \\
39(30.5) \\
27(21.1) \\
42(32.8) \\
17(13.3)\end{array}$ \\
\hline Number of people living in the house ${ }^{* * *}$ & $4(2-8)$ \\
\hline $\begin{array}{l}\text { Presence of a high-risk group individual at } \\
\text { home other than the patient }{ }^{* *}\end{array}$ & $41(32)$ \\
\hline Presence of a smoker** & $80(62.5)$ \\
\hline Age at diagnosis (year) ${ }^{* * *}$ & $6.0(1-16)$ \\
\hline Follow-up dutaion (year) & $3.0(0.5-14)$ \\
\hline Skin test positivity** & $74(71.8)$ \\
\hline Presence of additional allergic disease ${ }^{* *}$ & $43(39.4)$ \\
\hline Use of controlling drugs** & $83(76.1)$ \\
\hline Asthma under control** & $68(62.4)$ \\
\hline Presence of attacks the previous year** & $72(66.1)$ \\
\hline $\begin{array}{l}\text { *Mean } \pm \text { SD. } \\
{ }^{* *} \text { Number(\%). } \\
{ }^{* * *} \text { Median (min-max). }\end{array}$ & \\
\hline
\end{tabular}

asthmatic patients were in the high-risk group for influenza, and $23.4 \%$ knew that the vaccine was free-of-charge for asthma patients. As the source for information, physicians (59.5\%), radio-TV programs $(24.3 \%)$, and the internet (\%21.6\%) were stated most commonly. While vaccination rate for at least once in a lifetime in asthmatic children was $31 \%$, this rate was $15 \%$ in parents. Of the parents, while $6.3 \%$ got their children vaccinated in the $2019-2020$ flu season, $69.5 \%$ stated that they would not get their children vaccinated or that they did not have an idea on the matter. Of the parents who got their children vaccinated at least once in previous years, $42.5 \%$ changed his/her attitude negatively. Table 2 demonstrates the data regarding the knowledge and attitude of the parents on flu and vaccination.

When the parents' reasons for getting their children were asked, physician's recommendation (75\%) and being in the high-risk group (35\%) were the most commonly given answers. When the parents' reasons for not getting their children were asked, most common answers were not having sufficient knowledge on the vaccine $(36.1 \%)$ and the fear of its side effects $(32.1 \%)$, which were respectively followed by the fact that his/her child did not catch the flu often $(22.6 \%)$, he/she did not consider the flu a serious disease (13.1\%), and he/she though the vaccine was ineffective (11.9\%). 
Table 2. Knowledge and attitude of participating parents on the flu vaccine

\begin{tabular}{|c|c|}
\hline Feature (Number=128) & Number (\%) \\
\hline Those having knowledge on flu vaccine & $74(57.8)$ \\
\hline $\begin{array}{l}\text { Those knowing that asthma constitutes high-risk for the } \\
\text { flu disease }\end{array}$ & $60(47.6)$ \\
\hline $\begin{array}{l}\text { Those knowing that the flu vaccine is free-of-charge for } \\
\text { asthma patients }\end{array}$ & $29(23.4)$ \\
\hline $\begin{array}{l}\text { Information sources } \\
\text { Physicinas } \\
\text { Radio-TV programs } \\
\text { Internet } \\
\text { Publications on health } \\
\text { Health page of newspapers }\end{array}$ & $\begin{array}{l}44(59.5) \\
18(24.3) \\
16(21.6) \\
12(16.2) \\
3(4.1)\end{array}$ \\
\hline $\begin{array}{l}\text { Those having had at least one flu vaccine among } \\
\text { asthmatic children }\end{array}$ & $40(31)$ \\
\hline $\begin{array}{l}\text { Those having had at least one flu vaccine among } \\
\text { parents }\end{array}$ & $19(15)$ \\
\hline $\begin{array}{l}\text { In the } 2019-2020 \text { flu season, } \\
\text { Those who have already/will get their children } \\
\text { vaccinated } \\
\text { Those who will not get their children vaccinated/ } \\
\text { do not have an idea }\end{array}$ & $\begin{array}{l}39(30.5) \\
89(69.5)\end{array}$ \\
\hline
\end{tabular}

The characteristics of the patients who got the flu vaccine at least once and those who did not were compared in order to investigate the factors affecting the flu vaccine. Demographic data of the two groups were found similar. Follow-up duration of the group having had the vaccine was found longer than the unvaccinated group (median 5 and 2 years respectively, $p<0.001$ ). Age at diagnosis was younger but not statistically significant (mean 5 and 7 years respectively, $p=$ 0.128 ). Additional disease presence was more common in the unvaccinated group $(46.2 \%, 22.6 \%, p=0.023)$. Skin test positivity, controlling drug use, the disease being under control, and the presence of attacks in the previous season were similar in both groups. When the patients were grouped accord- ing to 2-year and 5-year follow-up periods, it was seen that the vaccination rate in those followed for 2 years and more increased to $40 \%$ from $10 \%$ and the vaccination rate in those followed for 5 years and more increased to $50 \%$ from $15 \%$ ( $p=$ 0.001 and $p<0.001$, respectively) .

The rate of being informed on the flu vaccine was higher in the parents of vaccinated patients compared to the unvaccinated $(82.5 \%, 46.6 \%$, respectively $p<0.001)$. Same parents knew at a higher rate that asthmatic children were at the high-risk group in terms of the flu disease and that the vaccine was free-of-charge compared to the parents of unvaccinated patients $(74.4 \%, 35.6 \%, \mathrm{p}<0.001$ and $45 \%, 13.1 \%, \mathrm{p}<$ 0.001 , respectively). Although parents in both groups marked physicians most commonly as their information source, this rate was $85 \%$ and $39 \%$ in the vaccinated and unvaccinated group, respectively $(p<0.001)$. Internet use as the information source was more common in the parents of unvaccinated patients $(34.1 \%, 6.1 \%, p=0.004)$. Parents considering to get their children vaccinated or having already got their children vaccinated this year were more in the previously vaccinated group compared to the unvaccinated $(57.5 \%, 18.2 \%, \mathrm{p}<0.001)$. Vaccination rates at least once of the parents themselves was higher in the group who got their children vaccinated compared to those who did not $(30 \%, 8 \%$, respectively $p=0.001)$. Table 3 demonstrates the knowledge and attitude of the groups according to vaccination status.

\section{Discussion}

It was determined in this study that more than half of the parents with asthmatic children had information on the flu vaccine, approximately half of them knew that asthma was considered a risk in terms of the flu disease, and despite all, the frequency of getting their asthmatic children vaccinated at least once in a lifetime remained under one-third of the patients. Moreover, while the most common reason to get

Table 3. Comparison of the knowledge and attitude of the parents of vaccinated and unvaccinated children against the flu

\begin{tabular}{|c|c|c|c|}
\hline \multirow[b]{2}{*}{ Feature } & \multicolumn{2}{|c|}{ Number (\%) } & \multirow[b]{2}{*}{$\mathbf{p}$} \\
\hline & $\begin{array}{l}\text { Vaccinated } \\
\qquad(n=40)\end{array}$ & $\begin{array}{l}\text { Unvaccinated } \\
\qquad(\mathrm{n}=88)\end{array}$ & \\
\hline Those having knowledge on flu vaccine & $33(82.5)$ & $41(46.6)$ & $<0.001$ \\
\hline Those knowing that asthma constitutes high-risk for the flu disease & $29(74.4)$ & $31(35.6)$ & $<0.001$ \\
\hline Those knowing that the flu vaccine is free-of-charge for asthma patients & $18(45.0)$ & $11(13.1)$ & $<0.001$ \\
\hline $\begin{array}{l}\text { Information sources } \\
\text { Physicians } \\
\text { Internet } \\
\text { Publications on health }\end{array}$ & $\begin{array}{l}28(84.8) \\
2(6.1) \\
2(6.1)\end{array}$ & $\begin{array}{l}16(39.0) \\
14(34.1) \\
10(24.4)\end{array}$ & $\begin{array}{c}<0.001 \\
0.004 \\
0.033\end{array}$ \\
\hline Those having had at least one flu vaccine among parents & $12(30.0)$ & $7(8.0)$ & 0.001 \\
\hline $\begin{array}{l}\text { In the 2019-2020 flu season } \\
\text { Those who have already/will get their children vaccinated } \\
\text { Those who will not get their children vaccinated/ do not have an idea }\end{array}$ & $\begin{array}{l}23(57.5) \\
17(42.5)\end{array}$ & $\begin{array}{l}16(18.2) \\
72(81.8)\end{array}$ & $<0.001$ \\
\hline
\end{tabular}


their children vaccinated was physician's recommendation, the most common reason for not getting their children vaccinated was lack of knowledge, and the increase in follow-up duration was found to increase vaccination rates.

Even though flu vaccine is recommended to be given to asthmatic children every year, vaccination rates differ from country to country and year to year depending on the different vaccination policies practiced and mostly do not exceed $50 \%(11-17,19,20)$. The increase in vaccination rates seen especially in risk groups worldwide following the 2009 HIN1 epidemic was not observed in our country $(13,14)$. It has been reported that while vaccination rates was $52 \%$ in the 2007-2008 season, they were found as $45.7 \%$ in the $2009-2010$ season in the same patient group in Ankara $(15,16)$. Different from these studies conducted in the end of the season, vaccination rate in asthmatic patients in Denizli was found quite low (33\%) in the 2016-2017 season (17). This difference can be related to regional factors and year or there may have been participants who did not get the vaccine yet. Similar to our study, vaccination rate at the time of survey was found low (6\%) since the study began at the beginning of the season. In our study, the reason for choosing this period was to raise awareness of the parents on the matter through the survey and not miss the opportunity of giving education. When the parents were asked to share their decision on getting the flu vaccine this season, it was seen that the rate of the parents stating that they would get their children vaccinated was over $30 \%$, but still lower than previous studies $(15,16)$. Vaccination rate at least once in a lifetime (31\%) was found lower compared to previous studies carried out in Ankara and İstanbul (70\%,47\% respectively) $(15,20)$. This condition made us consider that it could be related to the patient profile of our hospital, and further multi-center studies are required to reflect the current condition in the city (Izmir).

In our study, the fact that a higher positive response rate was obtained in the vaccinated group for the questions oriented at measuring the knowledge level of the parents regarding vaccine puts forwards the significant relation between knowledge and attitude. Similarly, in a study by Büyüktiryaki et al. (16), it has been observed that the parents of vaccinated patients were more commonly aware of the severity of the disease and believed in the necessity and safety of the vaccine.

The reason for getting their children vaccinated was the physicians' recommendation in $75 \%$ of the parents with vaccinated children. Similar results have been found in other studies conducted in our country $(74-80 \%)(15,17)$. Even though physicians were ranked as the most common source of information in both vaccinated and unvaccinated groups, this rate was detected as twofold in the vaccinated group compared to the unvaccinated. The most common reason for not getting the vaccine was lack of knowledge, which was reported by approximately one-third of the patients $(15,17)$. Parents in the unvaccinated group mostly got their current information on the internet and other information sources, and the fact that the vaccinated group rarely applied to these sources made us consider that individuals reaching correct information did not require any other source. The fear of side effects of the vaccine and that the flu is not a severe disease, which were two other reasons of not getting the vaccine in our study, suggest and support the lack of knowledge in unvaccinated individuals. As a result of the studies conducted so far, even though to what degree vaccination protects the patient from influenza-related asthma attacks is still unclear $(21,22)$, it has been shown that the vaccine itself does not trigger asthma attacks and inactive influenza vaccines are safe in terms of side effects in asthmatic children (22-24). It has been shown in previous studies on knowledge level and attitude regarding vaccines in our country that fear of side effects and the suspicion towards the efficacy of the vaccine have important effects on not getting the vaccine. In a study by Kaya et al. (20) including children and adult patients, the fear of side effects has been found quite low in the parents of pediatric patients, and one-third of adult patients has been determined not to get the vaccine due to this fear. This condition was attributed to the fact that parents remembered the safety of routine vaccines administered in pediatric patients. However, contrary to this finding, our study found that one-third of the parents did not get their child vaccinated because of fearing its side effects. This condition can be attributed to the fact that this unvaccinated group obtained information online and anti-vaccination campaigns run on these platforms have gained momentum in the last few years. Besides this, the number of parents who did not get their children vaccinated for thinking that the vaccine was not effective was quite low. Having had very different results in various studies $(6-68 \%)$, regional differences and the scope of the survey questions could be the reasons for these different outcomes $(17,20)$. Arık Yılmaz (17), in his study, has specified that most of the parents remarked that they did not have an opinion on the questions regarding efficiency and side effects, which supports the general insufficiency of the information given on vaccines.

In our study, the follow-up duration of vaccinated patients was found longer than the unvaccinated ones, and a 2-year follow and a 5-year follow were found to have increased vaccination to the rate of $40 \%$ and $50 \%$, respectively. This condition suggested that increasing follow-up duration positively affects the attitude of the patients by enhancing information exchange with the physician. In addition to the effect of the follow-up duration, the high frequency in patients stating that they would not get the seasonal flu vaccine this season even though they had received it at least once before makes us consider that physicians should inform the patients on seasonal flu vaccine every year, and continuity of patient education is significant. 
There are limitations to our study. First, the study is a survey study, and the participants may have not responded correctly due to haste or reservation. Second, the study has no control group. However, it is our belief that this did not affect the results of our study since our primary aim was to investigate the knowledge level and vaccination of asthmatic patients.

To conclude, it was seen in our study that vaccination rates of asthmatic children were quite low. Higher vaccination rate in the group with a longer period of follow-up shows that information obtained from physicians regarding vaccines properly direct patients in vaccination. Therefore, it is vital for physicians to reiterate the significance of vaccination in highrisk groups like asthma. Responsibility lies on the family practitioners and pediatricians following the patients.

Ethics Committe Approval: Approval was received from the SBÜ İmir Tepecik Training and Research Hospital Non-Interventional Clinical Research Ethics Board prior to our study (Date: 13/11/2019, Decision no: 2019/16-7).

Informed Consent: Patient consent was obtained.

Peer-review: Externally peer-reviewed.

Author Contributions: Concept - SEA, EKÖ; Design - SEA, TT, EKÖ; Supervision - EKÖ, DYÇ; Resource - SEA, EEÖ; Data Collection and/ or Processing - SEA, TT, EEÖ; Analysis and/or Interpretation - SEA, TT; Literature Search - SEA, TT; Writing - SEA; Critical Review - EKÖ, TT, DYÇ.

Conflict of Interest: All authors declare that they have no conflicts of interest or funding to disclose.

Financial Disclosure: The authors declared that this study has received no financial support.

\section{References}

1. Influenza (Flu). (Erişim tarihi: 07.11.2020, https://www.cdc.gov/flu/index.htm) [CrossRef]

2. Vaccines against influenza WHO position paper-November 2012. Wkly Epidemiol Rec. 2012 Nov 23;87(47):461-76. [CrossRef]

3. Flannery $B$, Reynolds $S B$, Blanton $L$, Santibanez TA, O'Halloran A, Lu $P$-J, et al. Influenza vaccine effectiveness against pediatric deaths: 2010-2014. Pediatrics 2017 May;139(5): e20164244. [CrossRef]

4. Trent CA, Zimbro KS, Rutledge CM. Barriers in asthma care for pediatric patients in primary care. J Pediatr Health Care Jan-Feb 2015;29(1):70-9. [CrossRef]

5. Asthma.(Erişimtarihi: 07.11.2020, http://www.who.int/en/news-room/ fact sheets/detail/asthma). [CrossRef]

6. Bloom B, Jones LI, Freeman G. Summary health statistics for U.S. children: National Health Interview Survey, 2012. Vital and Health Statistics, 10(258), 1-81. [CrossRef]
7. Johnston SL, Pattemore PK, Sanderson G, Smith S, Lampe F, Josephs $L$, et al. Community study of role of viral infections in exacerbations of asthma in 9-11 year old children. BMJ 1995;310:1225-9. [CrossRef]

8. Flu \& People with Asthma (Erişim tarihi: 07.11.2020, https://www.cdc. gov/flu/asthma) [CrossRef]

9. Grohskopf LA, Sokolow LZ, Broder KR, Olsen SJ, Karron RA, Jernigan DB, Breese JS. Prevention and Control of Seasonal Influenza with Vaccines. MMWR Recomm Rep 2016;65 (No. RR-5):1-54. [CrossRef]

10. Influenza (Seasonal). (Erişim tarihi: 07.11.2020, https://www.who.int/ news-room/fact-sheets/detail/influenza-(seasonal). [CrossRef]

11. Gnanasekaran SK, Finkelstein JA, Hohman K, O'Brien M, Kruskal B, Lieu TA. Parental perspectives on influenza vaccination among children with asthma. Public Health Rep 2006;121: 181-8. [CrossRef]

12. Rance F, Chave C, De Blic J, Deschildre A, Donato L, Dubus JC, et al. Low influenza vaccination coverage in asthmatic children in France in 2006-2007. Eurosurveillance 2008;13:1-6. [CrossRef]

13. Weil-Olivier C, Lina B. Vaccination coverage with seasonal and pandemic influenza vaccines in children in France, 2009-2010 season. Vaccine 2011 Sep 16;29(40):7075-9. [CrossRef]

14. Simon AE, Ahrens $K A$, Akinbami LJ. Influenza Vaccination Among US Children With Asthma, 2005-2013. Acad Pediatr 2016;16(1):68-74. [CrossRef]

15. Soyer OU, Hudaverdiyev S, Civelek E, Isik E, Karabulut E, Kocabas C, et al. Parental perspectives on influenza vaccination in children with asthma. Pediatr Pulmonol 2011;46:139-44. [CrossRef]

16. Buyuktiryaki B, Soyer OU, Erkocoglu M, Dogan A, Azkur D, Kocabas CN, et al. What a pandemic teaches us about vaccination attitudes of parents of children with asthma. Vaccine 2014;32:2275-80. [CrossRef]

17. Arık Yılmaz E. Astımlı Çocukların Ebeveynlerinin Mevsimsel Inflüenza Aşısı Hakkındaki Görüşlerinin Değerlendirilmesi. Asthma Allergy Immunol 2018;16:24-33. [CrossRef]

18. Global Initiative for Asthma (GINA). Global strategy for asthma management and prevention, 2019. (Erişim tarihi: 07.11.2019, https://ginasthma.org/reports/) [CrossRef]

19. Rajaram S, Steffey A, Blak B, Hickman M, Christensen H, Caspard H. Uptake of childhood influenza vaccine from 2012- 2013 to 2014-2015 in the UK and the implications for high-risk children: A retrospective observational cohort study. BMJ Open 2016;6:e010625. [CrossRef]

20. Kaya A, Altinel N, Karakaya G, Cetinkaya F. Knowledge and attitudes among patients with asthma and parents and physicians towards influenza vaccination. Allergol Immunopathol (Madr) 2017;45(3):240-3. [CrossRef]

21. Bueving HJ, Bernsen RM, de Jongste JC, van Suijlekom-Smit LW, Rimmelzwaan GF, Osterhaus $A D$, et al. Influenza vaccination in children with asthma: Randomized double-blind placebo-controlled trial. Am J Respir Crit Care Med 2004;169(4):488-93. [CrossRef]

22. Cates $C$, Rowe BH. Vaccines for preventing influenza in people with asthma. Cochrane Database Syst Rev. 2013;(2):CD000364. [CrossRef]

23. The American Lung Association Asthma Clinical Research Centers. The safety of inactivated influenza vaccine in adults and children with asthma. N Engl J Med 2001;345(21):1529-36. [CrossRef]

24. Bueving HJ, Bernsen RM, de Jongste JC, van Suijlekom-Smit LW, Rimmelzwaan $G F$, Osterhaus $A D$, et al. Does influenza vaccination exacerbate asthma in children? Vaccine 2004 Nov 15;23(1):91-6. [CrossRef] 